
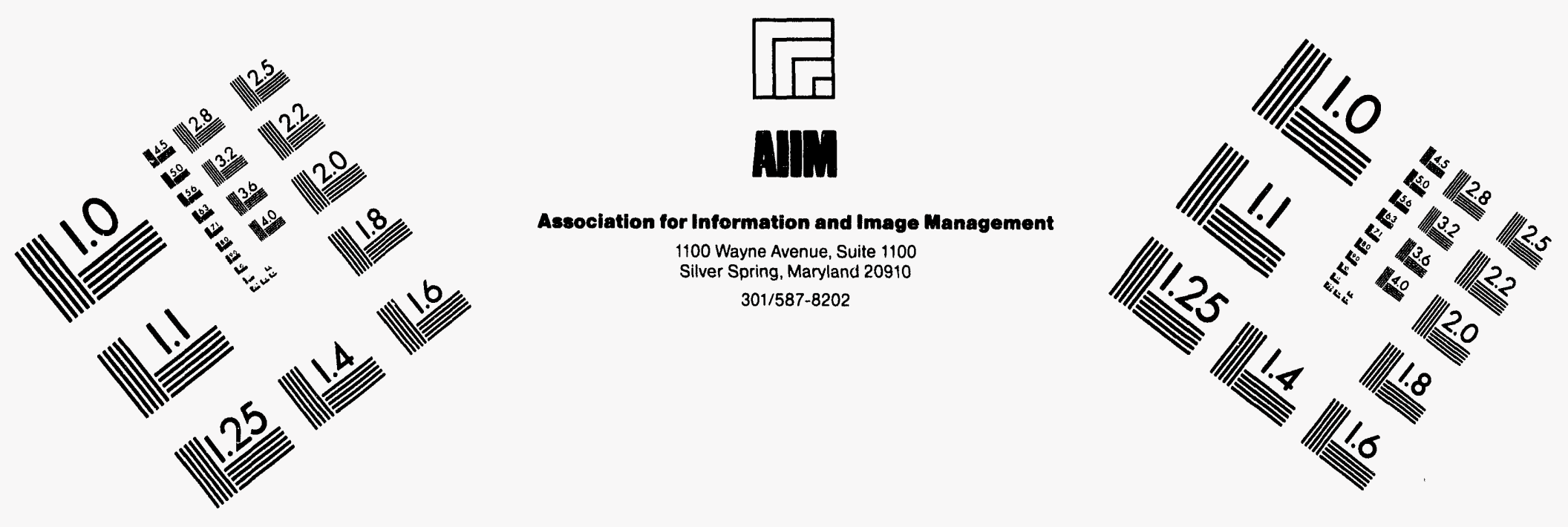

\title{
Centimeter
}

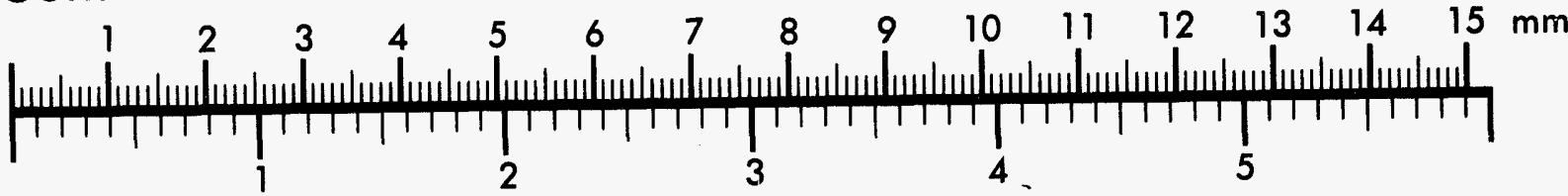
Inches
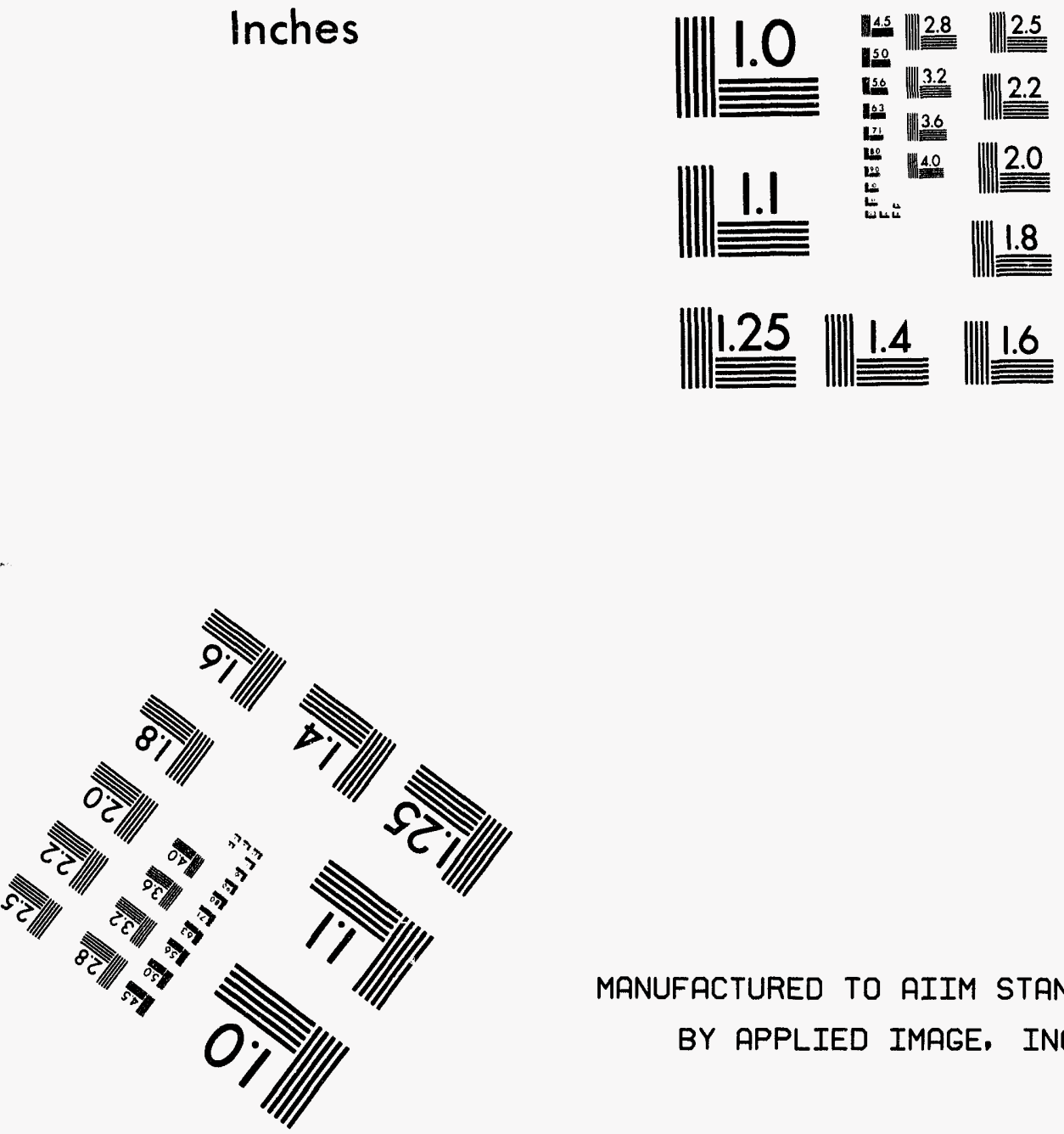

MANUFACTURED TO AIIM STANDARDS

BY APPLIED IMAGE, INC.

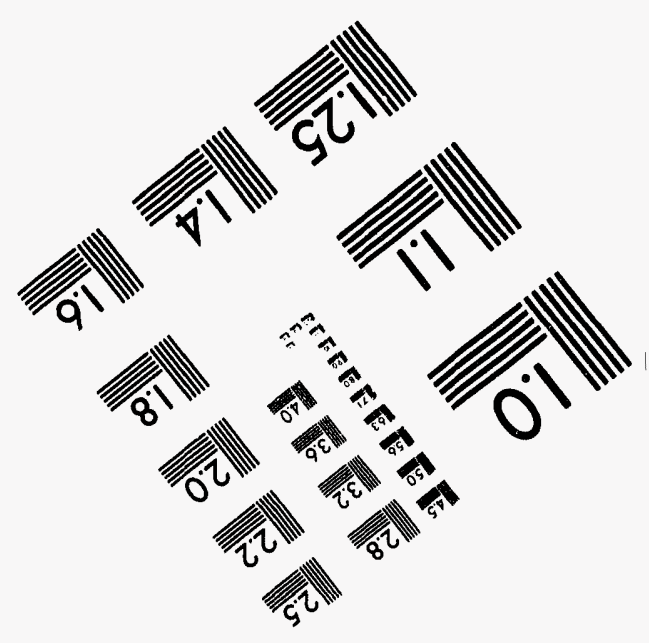



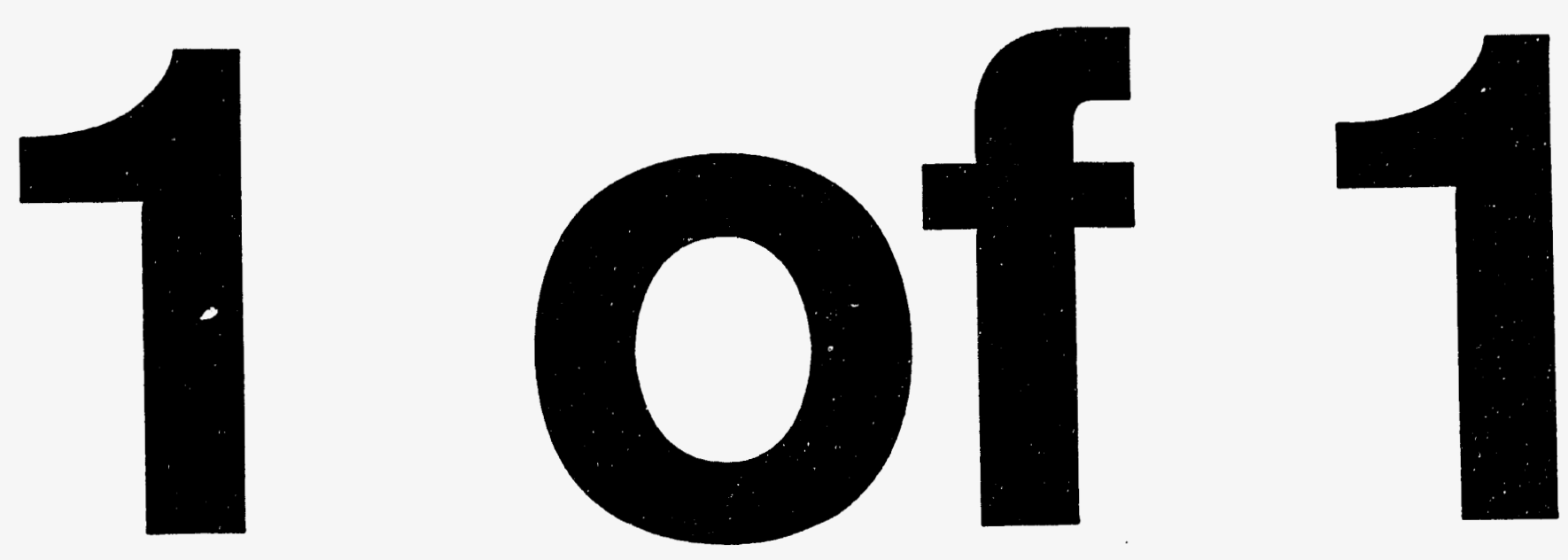


\section{Bonneville Project Act, Federal Columbia River Transmission System Act and Other Related Legislation}

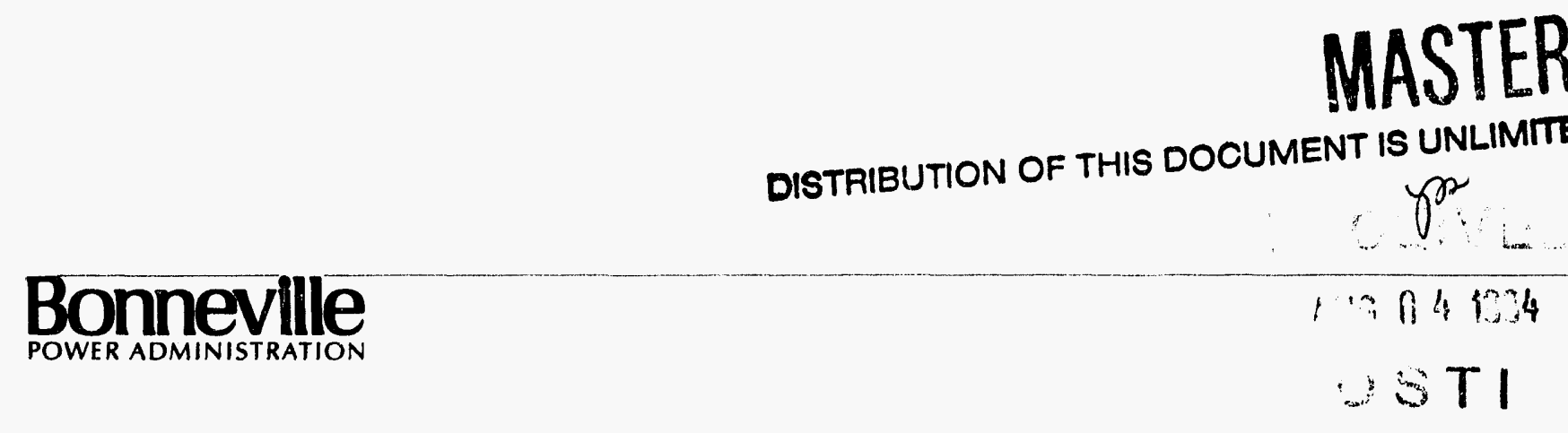




\title{
BONNEVILLE PROJECT ACT
}

\author{
as amended' \\ 16 U.S. Code Chapter 12B (1964 Ed.)
}

Act of August 20, 1937, Ch. 720, 50 Stat. 731

[Public No. 329 (H.R. 7642) - 75th Congress, 1st Session]

As amended by Act of March 6, 1940, Ch. 47, 54 Stat. 47

[Public No. 429 (H.R. 7270) - 76th Congress, 3rd Session]

As amended by Act of October 23, 1945, Ch. 433, 59 Stat. $546^{2}$

[Public No. 201 (H.R. 2690) - 79th Congress, 1st Session]

As amended by Act of July 26, 1946, Ch. 673, 60 Stat. 701

[Public No. 550 (S. 1516) - 79th Congress, 2d Session]

As amended by Act of June 14, 1966, 80 Stat. 200

[Public No. 448 (S. 1761) - 89th Congress, 2d Session]

\begin{abstract}
AN ACT
To authorize the completion, maintenance, and operation of Bonneville project for navigation, and for other purposes.

Be it enacted by the Senate and House of Representatives of the United States of America in Congress assembled, That for the purpose of improving navigation on the Columbia River, and for other purposes incidental thereto, the dam, locks, power plant, and appurtenant works now under construction at Bonneville, Oregon, and North Bonneville, Washington (hereinafter called Bonneville project), shall be completed, maintained, and operated under the direction of the Secretary of the Army and the supervision of the Chief of Engineers, subject to the provisions of this Act relating to the powers and duties of the Bonneville power administrator provided for in section 2 (a) (hereinafter called the administrator) respecting the transmission and sale of electric energy generated at said project. The Secretary of
\end{abstract}

Footnotes follow text, beginning on page 9 . 
the Army shall provide, construct, operate, maintain, and improve at Bonneville project such machinery, equipment, and facilities for the generation of electric energy as the administrator may deem necessary to develop such electric energy as rapidly as markets may be found therefor. The electric energy thus generated and not required for the operation of the dam and locks at such project and the navigation facilities employed in connection therewith shall be delivered to the administrater, for disposition as provided in this Act. [50 Stat. 731-732; 16 U.S.C. 832. $]^{3}$

SEC. 2. (a) The electric energy generated in the operation of the said Bonneville project shall be disposed of by the said administrator as hereinafter provided. ${ }^{4}$ The administrator shall be appointed by the Secretary of the Interior; shall be responsible to said Secretary of the Interior; ${ }^{5}$ and shall maintain his principal office at a place selected by him in the vicinity of the Bonneville project. The administrator shall, as hereinafter provided, make all arrangements for the sale and disposition of electric energy generated at Bonneville project not required for the operation of the dam and locks at such project and the navigation facilities employed in connection therewith. He shall act in consultation with an advisory board composed of a representative designated by the Secretary of the Army, a representative designated by the Secretary of the Interior, a representative designated by the Federal Power Commission, and a representative designated by the Secretary of Agriculture. ${ }^{6}$. The form of administration herein established for the Bonneville project is intended to be provisional pending the establishment of a permanent administration for Bonneville and other projects in the Columbia River Basin. The Secretary of the Army shall install and maintain additional machinery, equipment, and facilities for the generation of electric energy at the Bonneville project when in the judgment of the administrator such additional generating facilities are desirable to meet actual or potential market requirements for such electric energy. The Secretary of the Army shall schedule the operations of the several electrical generating units and appurtenant equipment of the Bonneville project in accordance with the requirements of the administrator. The Secretary of the Army shall provide and maintain for the use of the administrator at said Bonneville project adequate station space and equipment, including such switches, switchboards, instruments, and dispatching facilities as may be required by the administrator for proper reception, handling, and dispatching of the electric energy produced at the said project, together with transformers and other equipment required by the administrator for the transmission of such energy from that place at suitable voltage to the markets which the administrator desires to serve. ${ }^{7}$ The office of the Administrator of the Bonneville project is hereby constituted an office in the Department of the Interior and shall be under the jurisdiction and control of the Secretary of the Interior. ${ }^{8}$ All functions vested in the Administrator of the Bonneville project under this Act may be exercised by the Secretary of the Interior and, subject to his supervision and direction, by the Administrator and other personnel of the project. [50 Stat. 732, as amended by 54 Stat. 47 and 59 Stat. 547; 16 U.S.C. 832a(a).]

(b) In order to encourage the widest possible use of all electric energy that can be generated and marketed and to provide reasonable outlets therefor, and to prevent the monopolization thereof by limited groups, the administrator is authorized and directed to provide, construct, operate, maintain, and improve such 
electric transmission lines and substations, and facilities and structures appurtenant thereto, as he finds necessary, desirable, or appropriate for the purpose of transmitting electric energy, available for sale, from the Bonneville project to existing and potential markets, and, for the purpose of interchange of electric energy, to interconnect the Bonneville project with other Federal projects and publicly owned power systems now or hereafter constructed. ${ }^{9}$ [50 Stat. 732 ; 16 U.S.C. $832 \mathrm{a}(\mathrm{b})$.]

(c) The administrator is authorized, in the name of the United States, to acquire, by purchase, lease, condemnation, or donation, such real and personal property, or any interest therein, including lands, easements, rights-of-way, franchises, electric transmission lines, substations, and facilities and structures appurtenant thereto, as the administrator finds necessary or appropriate to carry out the purposes of this Act. ${ }^{10}$ Title to all property and property rights acquired by the administrator shall be taken in the name of the United States. [50 Stat. 732-733; 16 U.S.C. $832 \mathrm{a}(\mathrm{c})$.

(d) The administrator shall have power to acquire any property or property rights, including patent rights, which in his opinion are necessary to carry out the purposes of this Act, by the exercise of the right of eminent domain and to institute condemnation proceedings therefor in the same manner as is provided by law for the condemnation of real estate. ${ }^{11}$ [50 Stat. 733; 16 U.S.C. 832a(d).]

(e) The administrator is authorized, in the name of the United States, to sell, lease, or otherwise dispose of such personal property as in his judgment is not required for the purposes of this Act and such real property and interests in land acquired in connection with construction or operation of electric transmission lines or substations as in his judgment are not required for the purposes of this Act: Provided, however, That before the sale, lease, or disposition of real property or transmission lines, as herein provided, the administrator shall secure the approval of the President of the United States. ${ }^{12}$ [50 Stat. 733; 16 U.S.C. 832a(e).]

(f) Subject only to the provisions of this Act, the Administrator is authorized to enter into such contracts, agreements, and arrangements, including the amendment, modification, adjustment, or cancellation thereof and the compromise or final settlement of any claim arising thereunder, and to make such expenditures, upon such terms and conditions and in such manner as he may deem necessary. [50 Stat. 733, as amended by 59 Stat. $546 ; 16$ U.S.C. $832 a(f)$.

SEC. 3. As employed in this Act, the term "public body", or "public bodies", means States, public power districts, counties, and municipalities, including agencies or subdivisions of any thereof.

As employed in this Act, the term "cooperative", or "cooperatives", means any form of non-profit-making organization or organizations of citizens supplying, or which may be created to supply, members with any kind of goods, commodities, or services, as nearly as possible at cost. [50 Stat. 733; 16 U.S.C. 832b.]

SEC. 4. (a) In order to insure that the facilities for the generation of electric energy at the Bonneville project shall be operated for the benefit of the general public, and particularly of domestic and rural consumers, the administrator shall at all times, in disposing of electric energy generated at said project, give preference and priority to public bedies and cooperatives. [50 Stat. 733; 16 U.S.C. $832 \mathrm{c}(\mathrm{a})$. 
(b) To preserve and protect the preferential rights and priorities of public bodies and cooperatives as provided in section (a) and to effectuate the intent and purpose of this Act that at all times up to January 1, 1942, there shall be available for sale to public bodies and cooperatives not less thais 50 per centum of the electric energy produced at the Bonneville project, it shall be the duty of the administrator in making contracts for the sale of such energy to so arrange such contracts as to make such 50 per centum of such energy available to said public bodies and cooperatives until January 1, 1942: Provided, That the electric energy so reserved for but not actually purchased by and delivered to such public bodies and cooperatives prior to January 1,1942, may be disposed of temporarily so long as such temporary disposition will not interfere with the purchase by and delivery to such public bodies and cooperatives at any time prior to January 1, 1942: Provided further, That nothing herein contained shall be construed to limit or impair the preferential and priority rights of such public bodies or cooperatives after January 1, 1942; and in the event that after such date there shall be conflicting or competing applications for an allocation of electric energy between any public body or cooperative on the one hand and a private agency of any character on the other, the application of such public body or cooperative shall be granted. [50 Stat. 733, as amended by 54 Stat. $47 ; 16$. U.S.C. $832 \mathrm{c}(\mathrm{b})$.]

(c) An application by any public body or cooperative for an allocation of electric energy shall not be denied, or another application competing or in conflict therewith be granted, to any private corporation, company, agency, or person, on the ground that any proposed bond or other security issue of any such public body or cooperative, the sale of which is necessary to enable such prospective purchaser to enter into the public business of selling and distributing the electric energy proposed to be purchased, has not been authorized or marketed, until after a reasonable time, to be determined by the administrator, has been afforded such public body or cooperative to have such bond or other security issue authorized or marketed. [50 Stat. 734; 16 U.S.C. 832c(c).]

(d) It is declared to be the policy of the Congress, as expressed in this Act, to preserve the said preferential status of the public bodies and cooperatives herein referred to, and to give to the people of the States within economic transmission distance of the Bonneville project reasonable opportunity and time to hold any election or elections or take any action necessary to create such public bodies and cooperatives as the laws of such States authorize and permit, and to afford such public bodies or cooperatives reasonable time and opportunity to take any action necessary to authorize the issuance of bonds or to arrange other financing necessary to construct or acquire necessary and desirable electric distribution facilities, and in all other respects legally to become qualified purchasers and distributors of electric energy available under this Act. [50 Stat. $734 ; 16$ U.S.C. $832 \mathrm{c}(d)$. ]

SEC. 5. (a) Subject to the provisions of this Act and to such rate schedules as the Federal Power Commission may approve, as hereinafter provided, the administrator shall negotiate and enter into contracts for the sale at wholesale of electric energy, either for resale or direct consumption, to public bodies and cooperatives and to private agencies and persons and for the disposition of electric energy to Federal agencies. ${ }^{13}$ Contracts for the sale of electric energy to any private person or agency other than a privately owned public utility engaged in selling 
electric energy to the general public, shall contain a provision forbidding such private purchaser to resell any of such electric energy so purchased to any private utility or agency engaged in the sale of electric energy to the general public, and requiring the immediate canceling of such contract of sale in the event of violation of such provision. Contracts entered into under this subsection shall be binding in accordance with the terms thereof and shall be effective for such period or periods, including renewals or extensions, as may be provided therein, not exceeding in the aggregate twenty years from the respective dates of the making of such contracts. Contracts entered into under this subsection shall contain (1) such provisions as the administrator and purchaser agree upon for the equitable adjustment of rates at appropriate intervals, not less frequently than once in every five years, and (2) in the case of a contract with any purchaser engaged in the business of selling electric energy to the general public, the contract shall provide that the administrator may cancel such contract upon five years' notice in writing if in the judgment of the administrator any part of the electric energy purchased under such contract is likely to be needed to satisfy the requirements of the said public bodies or cooperatives referred to in this Act, and that such cancellation may be with respect to all or any part of the electric energy so purchased under said contract to the end that the preferential rights and priorities accorded public bodies and cooperatives under this Act shall at all times be preserved. Contracts entered into with any utility engaged in the sale of electric energy to the general public shall contain such terms and conditions, including among other things, stipulations concerning resale and resale rates by any such utility, as the administrator may deem necessary, desirable or appropriate to effectuate the purposes of this Act and to insure that resale by such utility to the ultimate consumer shall be at rates which are reasonable and nondiscriminatory. Such contract shall also require such utility to keep on file in the office of the administrator a schedule of all its rates and charges to the public for electric energy and such alterations and changes therein as may be put into effect by such utility. [ 50 Stat. $734-735$, as amended by 59 Stat. 546; 16 U.S.C. 832 d(a).]

(b) The administrator is authorized to enter into contracts with public or private power systems for the mutual exchange of unused excess power upon suitable exchange terms for the purpose of economical operation or of providing emergency or break-down relief. [50 Stat. 735; 16 U.S.C. 832d(b).]

SEC. 6. Schedules of rates and charges for electric energy produced at the Bonneville project and sold to purchasers as in this Act provided shall be prepared by the administrator and become effective upon confirmation and approval thereof by the Federal Power Commission; and such rates and charges shall also be applicable to dispositions of electric energy to Federal agencies. Subject to confirmation and approval by the Federal Power Commission, such rate schedules may be modified from time to time by the administrator, and shall be fixed and established with a view to encouraging the widest possible diversified use of electric energy. ${ }^{14}$ The said rate schedules may provide for uniform rates or rates uniform throughout prescribed transmission areas in order to extend the benefits of an integrated transmission system and encourage the equitable distribution of the electric energy developed at the Bonneville project. ${ }^{15}$ [50 Stat. 735, as amended by 59 Stat. 546; 16 U.S.C. 832 e.] 
SEC. 7 It is the intent of Congress that rate schedules for the sale of electric energy which is or may be generated at the Bonneville project in excess of the amount required for operating the dam, locks, and appurtenant works at said project shall be determined with due regard to and predicated upon the fact that such electric energy is developed from water power created as an incident to the construction of the dam in the Columbia River at the Bonneville project for the purposes set forth in section 1 of this Act. Rate schedules shall be drawn having regard to the recovery (upon the basis of the application of such rate schedules to the capacity of the electric facilities of Bonneville project) of the cost of producing and transmitting such electric energy, including the amortization of the capital investment over a reasonable period of years. ${ }^{16}$ Rate schedules shall be based upon an allocation of costs made by the Federal Power Commission. ${ }^{17}$ In computing the cost of electric energy developed from water power created as an incident to and a byproduct of the construction of the Bonneville project, the Federal Power Commission may allocate to the costs of electric facilities such a share of the cost of facilities having joint value for the production of electric energy and other purposes as the power development may fairly bear as compared with such other purposes. [50 Stat. 735; 16 U.S.C. 832f.]

SEC. 8 Notwithstanding any other provision of law, all purchases and contracts made by the administrator or the Secretary of the Army for supplies or for services except for personal services, shall be made after advertising, in such manner and at such times, sufficiently in advance of opening bids, as the administrator or Secretary of the Army, as the case may be, shall determine to be adequate to insure notice and opportunity for competition. Such advertisement shall not be required, however, when (1) an emergency requires immediate delivery of the supplies or performance of the services; or (2) repair parts, accessories, supplemental equipment, or services are required for supplies or services previously furnished or contracted for; or (3) the aggregate amount involved in any purchase of supplies or procurement of services does not exceed $\$ 500$; in which cases such purchases of supplies or procurement of services may be made in the open market in the manner common among businessmen. ${ }^{18}$ In comparing bids and in making awards, the administrator or the Secretary of the Army, as the case may be, may consider such factors as relative quality and adaptability of supplies or services, the bidder's financial responsibility, skill, experience, record of integrity in dealing, and ability to furnish repairs and maintenance services, the time of delivery or performance offered, and whether the bidder has complied with the specifications. [50 Stat. 735-736; 16 U.S.C. 832g.]

SEC. 9 (a) The administrator, subject to the requirements of the Federal Water Power Act, ${ }^{19}$ shall keep complete and accurate accounts of operations, including all funds expended and received in connection with transmission and sale of electric energy generated at the Bonneville project, and in the maintenance of such accounts, appropriate obligations shall be established for annual and sick leave of absence as earned. The Administrator shall, after the. close of each fiscal year, obtain an independent commercial-type audit of such accounts. ${ }^{20}$ The forms, systems, and procedures prescribed by the Comptroller General for the Administrator's appropriation and fund accounting shall be in accordance with the requirements of the Federal Water Power Act with respect to accounts of electric 
operations of public utilities and the regulations of the Federal Power Commission pursuant thereto. [50 Stat. 736 , as amended by 59 Stat. $547 ; 16$ U.S.C. $832 \mathrm{~h}(a)$.]

(b) The administrator may make such expenditures for offices, vehicles, furnishings, equipment, supplies, and books; for attendance at meetings; and for such other facilities and services as he may find necessary for the proper administration of this Act. ${ }^{21}$ [50 Stat. 736; 16 U.S.C. $\left.832 \mathrm{~h}(\mathrm{~b}).\right]$

(c) Deleted. 22

SEC. 10. (a) The Secretary of the Interior shall appoint, without regard to the civil-service laws, an Assistant Administrator, chief engineer, and general counsel $^{23}$ and shall fix the compensation of each in accordance with the Classification Act of 1949, as amended. The Assistant Administrator shall perform the duties and exercise the powers of the Administrator, in the event of the absence or sickness of the Administrator until such absence or sickness shall cease and in the event of a vacancy in the office of Administrator until a successor is appointed. [50 Stat. 736, as amended by 59 Stat. 547; 16 U.S.C. 832i(a).]

(b) The Administrator, the Secretary of the Army, and the Federal Power Commission, respectively, are authorized to appoint, subject to the civil-service laws, such officers and employees as may be necessary to carry out the purposes of this Act, the appointment of whom is not otherwise provided for, and to fix their compensation in accordance with the Classification Act of 1949, as amended. The Administrator may employ laborers, mechanics, and workmen in connection with construction work or the operation and maintenance of electrical facilities (hereinafter called "laborers, mechanics, and workmen"), subject to the civil-service laws, and fix their compensation without regard to any other laws, rules, or regulations relating to the payment of employees of the United States except the Classification Act of 1949, as amended, and the Civil Service Retirement Act, as amended, to the extent that they otherwise are applicable. ${ }^{24}$ The Administrator is further authorized to employ physicians, under agreement and without regard to civil-service laws or regulations, to make physical examinations of employees or prospective employees who are or may become laborers, mechanics, and workmen. The Administrator, the Secretary of the Army, and the Federal Power Commission, respectively, are also authorized to appoint, without regard to the civil-service laws, such experts as may be necessary for carrying out the functions entrusted to them under this Act and to fix the compensation of each of such experts in accordance with the Classification Act of 1949, as amended. ${ }^{25}$ [50 Stat. 736, as amended by 59 Stat. 547; 16 U.S.C. $832 \mathrm{i}(\mathrm{b})$.

(c) The Administrator may accept and utilize such voluntary and uncompensated services and with the consent of the agency concerned may utilize such officers, employees, or equipment of any agency of the Federal, State, or local governments which he finds helpful in carrying out the purposes of this Act; in connection with the utilization of such services, reasonable payments may be allowed for necessary travel and other expenses. [50 Stat. 736, as amended by 59 Stat. 547; 16 U.S.C. 832i(c).]

SEC. 11. All receipts from transmission and sale of electric energy generated at the Bonneville project shall be covered into the Treasury of the United States to the credit of miscellaneous receipts, save and except that the Treasury shall set up and maintain from such receipts a continuing fund of $\$ 500,000$, to the credit of the 
Administrator and subject to check by him, to defray emergency expenses and to insure continuous operation. There is hereby authorized to be appropriated from time to time, out of moneys in the Treasury not otherwise appropriated, such sums as may be necessary to carry out the provisions of this Act, including installation of equipment and machinery for the generation of electric energy and facilities for its transmission and sale. [50 Stat. 736; 16 U.S.C. 832j.]

SEC. 12. (a) The Administrator is hereby authorized to determine, settle, compromise, and pay claims and demands against the United States which are not in excess of $\$ 1,000$ and are presented to the Administrator in writing within one year from the date of accrual thereof, for any losses, injuries, or damages to persons or property, or for the death of persons, resulting from acts or omissions of employees acting within the scope of their employment pursuant to this Act. ${ }^{26}$ The Administrator is also authorized to determine, compromise, and settle any claims and demands of the United States for any losses, injuries, or damages to property under the Administrator's control, against other persons or public or private corporations. $^{27}$ The Administrator's determination, compromise, settlement, or payment of any of the claims referred to in this subsection shall be final and conclusive upon all officers of the Government, notwithstanding the provisions of any other Act to the contrary. When claims presented to the Administrator under this subsection arise, in whole or in part, out of any damage done to private ${ }^{28}$ property, the Administrator may repair all or any part of such damage in lieu of making such payments. [ 50 Stat. 736 , as amended by 59 Stat. 547-548; 16 U.S.C. $832 \mathrm{k}(\mathrm{a})$.

(b) The Administrator may, in the name of the United States, under the supervision of the Attorney General, bring such suits at law or in equity as in his judgment may be necessary to carry out the purposes of this Act; and he shall be represented in the prosecution and defense of all litigation, affecting the status or operation of Bonneville project by the United States attorneys for the districts, respectively, in which such litigation may arise, or by such attorney or attorneys as the Attorney General may designate as authorized by law, in conjunction with the regularly employed attorneys of the Administrator. ${ }^{29}$ [50 Stat. 736, as amended by 59 Stat. 548 and 60 Stat. $701 ; 16$ U.S.C. $832 k(b)$.

SEC. 13. If any provision of this Act or the application of such provisions to any person or circumstance shall be held invalid, the remainder of the Act and the application of such provision to persons or circumstances other than those as to which it is held invalid shall not be affected thereby. [50 Stat. 736; 16 U.S.C. 832l.] 


\section{FOOTNOTES}

1/ Throughout the Act th: following changes in terminology from the original statute have been inade in accordance with the authorities cited: (1) References to "Secretary of War" have been changed to "Secretary or the Army" in accordance with section 205(a) of the Act of July 26, 1947, 61 Stat. 501; (2) References to "Federal Water Power Act" have been retained although the correct designation is "Federal Power Act" (see section 320 of the Act of June 10, 1920, as added by section " 13 of the Act of August 26, 1935, 49 Stat. 863, 16 U.S.C. 791a); (3) References to "Classification Act of 1923, as amended" have been changed to "Classification Act of 1949, as amended" in accordance with section 1106 of the Act of October 28, 1949, 63 Stat. 954, and this latter term has been retained for simplicity of reference, even though it has been replaced by provisions of the codified Title 5 of the U.S. Code. Section 7(b) of P.L. 89-554 (80 Stat. 378) which enacted Title 5 declares that all references to a law replaced by the codified Title shall be deemed to refer to the corresponding provisions of the enacted codification; (4) Reference to "the Act of May 29, 1930 (46 Stat. 468), as amended" has been changed to "the Civil Service Retirement Act" in accordance with section 18 of the Act of May 29, 1930, as amended and renumbered by the Act of July 31, 1956, 70 Stat. 743, and has been retained as such for the reason stated under (3) above; (5) All references to "Administrator" (or "administrator" as contained in the original Act) have been retained as such. However, Reorganization Plan No. 3 of 1950, 64 Stat. 1262, 5 U.S.C. App., which became effective May 24, 1950, transferred to the Secretary of the Interior, "all functions of all other officers of the Department of the Interior and all functions of all agencies and employees of such Department." The Secretary was authorized to "make such provisions as he shall deem appropriate authorizing the performance by any other officer, or by any agency or employee, of the Department of the Interior of any function of the Secretary, including any function transferred to the Secretary by the provisions of this reorganization plan." By Secretarial Order 2563 (15 F.R. 3193) as replaced by 203 Departmental Manual 1.1, the Secretary assigned back to the officer, employee, or agency from whom or which the function was transferred, each function that was transferred to the Secretary by section 1 of Reorganization Plan No. 3 "until further notice." The current Secretarial Orders governing marketing of electrical energy by the Bonneville Power Administration are: Order No. 2860 as amended (27 F.R. 591, 28 F.R. 5273, 31 F.R. 13560); and Order No. 2883 (29 F.R. 14081). Marketing authority is also governed by the Federal Columbia River Transmission System Act of 1974, 16 U.S.C. 838(f), included infra.

2/ The Act of October 23, 1945, also made amendments to sections 1426, 1606, and 1607 of the Internal Revenue Code of 1939 and section 209 of the Social Security Act relative to certain employees of the Bonneville Power Administrator. These have been omitted because they have been subsequently repealed and replaced with more general language relative to government employees.

3/ For the purpose of identifying the sections which appeared in the original Act of 1937 and those which have been brought into the Act by amendment, references have been placed at the end of the sections. For example, the reference at the end of section 1, 50 Stat. 731-732, indicates that this section will be found in volume 50 of the Statutes at Large on pages 731 and 732. U.S. Code references are to the 1964 edition.

4/ Section 2 of the River and Harbor Act of 1945 (Act of March 2, 1945, 59 Stat. 10, 22) provides that "surplus electric energy generated at the dams authorized in this item [the four Lower Snake River dams] shall be delivered to the Secretary of the Interior for disposition in 
accordance with existing laws relating to the disposition of power at Bonneville Dam: Provided further, That nothing in this paragraph shall be construed as conferring the power of condem. nation of transmission lines * * " Virtually identical language appears in a later paragraph of the same Act authorizing McNary Dam. The Administrator also disposes of electric energy from other projects of the Corps of Engineers in the Pacific Northwest pursuant to authority of section 5 of the Flood Control Act of 1944 (Act of December 22, 1944, 58 Stat. 887, 890, 16 U.S.C. 825 s). This section reads as follows:

"SEC. 5. Electric power and energy generated at reservoir projects under the control of the Department of the Army and in the opinion of the Secretary of the Army not required in the operation of such projects shall be delivered to the Secretary of the Interior, who shall transmit and dispose of such power and energy in such manner as to encourage the most widespread use thereof at the lowest possible rates to consumers consistent with sound business principles, the rate schedules to become effective upon confirmation and approval by the Federal Power Commission. Rate schedules shall be drawn having regard to the recovery (upon the basis of the application of such rate schedules to the capacity of the electric facilities of the projects) of the cost of producing and transmitting such electric energy, including the amortization of the capital investment allocated to power over a reasonable period of years. Preference in the sale of such power and energy shall be given to public bodies and cooperatives. The Secretary of the Interior is authorized, from funds to be appropriated by the Congress, to construct or acquire; by purchase or other agreement, only such transmission lines and related facilities as may be necessary in order to make the power and energy generated at said projects available in wholesale quantities for sale on fair and reasonable terms and conditions to facilities owned by the Federal Government, public bodies, cooperatives, and privately owned companies. All moneys received from such sales shall be deposited in the Treasury of the United States as miscellaneous receipts."

The above section was construed in 41 Opinions of the Attorney General 236 (1955).

In addition, the Administrator disposes of power from certain reclamation projects in the region in accordance with the federal reclamation laws and (in the case of Grand Coulee Dam) Executive Order 8526, 5 F.R. 3390. Secretarial Order 2860 as amended (27 F.R. 591, 28 F.R. 5273, 31 F.R. 13560). See also section 8 of the Federal Columbia River Transmission System Act, cited in note 1 , supra.

Section 6 of the Act of July 27, 1954, 68 Stat. 573, 574, authorizing nonfederal development of the Priest Rapids site provides in part "Power surplus to the requirements of the licensee and other non-Federal marketing agencies (public or private) within the economic marketing area, as may be economically usable to the Federal System, may be made available to and may be purchased by the Bonneville Power Administrator at rates not higher than the rate charged such non.Federal marketing agencies, and under such terms and conditions as shall be mutually agreeable to the licensee and the Secretary of the Interior. Such power may be commingled with power from Federal dams in the Columbia River system for which the Bonneville Power Administrator has been designated marketing agent and shall be sold by the Administrator in accordance with the provisions of the Bonneville Project Act at established rate schedules."

5/ The words "shall receive a salary at the rate of $\$ 10,000$ per year;" have been omitted. The compensation of the Administrator is now covered by Level $V$ of the Federal Executive Salary Schedule, 5 U.S.C. 5316. 
6/ The functions of this advisory board have been transferred to the Secretary of the Interior, Reorganization Plan 4 of 1965, 30 F.R. 9353, 5 U.S.C. App.

$7 /$ See Memorandum of Understanciing No. 14-03-19250 dated November 16, 1970, between Bonnes: "le Power Administration and Corps of Engineers.

8/ The Bonneville Power Administration is now constituted as a bureau in the Department of the Interior. 105 Departmental Manual 2.2.

9/ The Secretary of the Iñterior administratively has indicated a division of marketing responsibility between the Bonneville Power Administration and the Bureau of Reclamation at certain points. By memoranda dated August 8 and August 15, 1950, respectively, the Secretary established the Continental Divide with respect to the Columbia and Missouri River Basins in Montana, and the California-Oregon border with respect to the Pacific Northwest and the Central Valley Project as the division points between the two agencies. See P.L. 88-552 excerpted below.

The Act of August .31, 1964, P.L. 88-552, 78 Stat. 756, 16 U.S.C. 837-837h, imposes lirnitations with respect to interconnections between "the Pacific Northwest," as therein defined, and the Pacific Southwest and contains provisions to guarantee Northwest consumers first call on electric energy generated at federal hydroelectric plants in the Northwest. Secretary's Order 2883 (29 F.R. 14081), issued pursuant thereto, designates those portions of Nevada, Utah, and Wyoming within the Columbia Drainage Basin and all of Idaho as within the BPA marketing arza. See also section 4 of the Federal Columbia River Transmission System Act cited in note 1, supra.

Construction and operation of two $500-\mathrm{kV}$ transmission lines to the international boundary at Blaine, Washington, is subject to the terms of Presidential Permit of October 27. 1945 (FPC Docket No. IT 5959), as amended.

See Executive Order 10485, 18 F.R. 5397, 16 U.S.C. 824, note following, for redelegation of Presidential Permit function to FPC. The Bell-Boundary interconnection was authorized by FPC Docket E 7176, September 3, 1964.

10/ See also (a) Federal Property and Administrative Services Act of 1949, as amended, and regulations issued thereunder; (b) 40 U.S.C. 255, 256; (c) note 4, supra; and (d) section 5a of the Federal Columbia River Transmission System Act cited in note 1, supra, regarding certain limitations on authority to condemn transmission lines.

The Act of August 5, 1939, 53 Stat. 1207, reserves to the United States for the Bonneville project a three-hundred-foot wide right-of-way easement across allotted and tribal lands on the Yakima Indian Reservation for electric transmission lines and such additional area as may be necessary for a substation. The reservation is subject to the consent of the individual allottees and the tribal council, to the approval of a definite location by the Secretary of the Interior, and to the payment of such compensation as the Secretary may determine. Condemnation is authorized if an allottee refuses to give his consent.

11/ See generally 40 U.S.C. 257-258f and Rule 71A FRCP, 28 U.S.C. App.

12/ Normally, excess or surplus real property is disposed of under the Federal Property and Administrative Services Act of 1949, as amended, and procedures established thereunder. See also section 13d of the Surplus Property Act of 1944. (50 Appendix U.S.C. 1622(d).) See G.S.A. Regulation 2-V-101.04.

13/ The Administrator's authority to contract for the sale or disposition of electric energy is also limited by the provisions of the Act of August 31, 1964, supra, note 9. 
14/ Section 9 of the Federal Columbia River Transmission System Act, cited in note 1, supra, similarly provides for schedules of rates and charges for the sale of all electric power made available to the Administrator pursuant to section 8 of that act be approved by the Federal Power Commission. "Such rate schedules may be modified from time to time by the Secretary of the Interior, acting by and through the Administrator, subject to confirmation and approval by the Federal Power Commission."

15/ Section 10 of the Federal Columbia River Transmission System Act provides that the Administrator charge uniform rates or rates uniform throughout prescribed transmission areas and that "the cost of the Federal transmission system shall be equitably allocated between Federal and non-Federal power utilizing such system."

16/ See sections 9(1), (2), and (3) of the Federal Columbia River Transmission System Act, cited in note 1, supra, which requires rates at sufficient levels to produce "such additional revenues. . . of the Administrator, to pay when due the principal of, premiums, discounts, and expenses in connection with the issuance of, and interest on all bonds issued and outstanding pursuant to this Act, and amounts required to establish and maintain reserves and other funds and accounts established in connection therewith." See also the Act of September 26, 1962, P.L. 87-701, 76 Stat. 599, authorizing arrangements for nonfederal construction of electric generating facilities at the Hanford New Production Reactor and which provides in part:

"Any losses to the Bonneville Power Administration in connection with the arrangements or sales authorized herein, shall be borne by its system customers through rate adjustments." (Sec. 112(d))

17/ Allocations of costs of projects constructed pursuant to the Reclamation laws are made by the Secretary of the Interior; Act of August 4, 1939, section 9, 53 Stat. 1187, 43 U.S.C. 485h. Allocations of costs of Corps of Engineers projects whose power is marketed pursuant to section 5 of the Flood Control Act of 1944 have been made by the Secretary of the Army.

18/ The Act of August 28, 1958, 72 Stat. 966, amended section 3709 of the Revised Statutes (41 U.S.C. 5) to permit contracts without advertising when the amount does not exceed $\$ 2,500$. Solicitor's Decision of October 13, 1958, held that this provision was applicable to Bonneville Power Administration. Additional special negotiating authority may be delegated by General Services Administration pursuant to section 302 of Federal Property and Administrative Services Act of 1949, as arnended, 41 U.S.C. 252. See also section 602(d)(20) of latter act as added by section 6 of P.L. 89-343, 79 Stat. 1303, 40 U.S.C. 474. This provides that nothing in that act shall impair or affect any authority of the Secretary of the Interior with respect to "procurement for program operations" under the Bonneville Project Act as amended.

19/ See sections 301-303 of the Federal Power Act as added by section 213 of the Act of August 26, 1935, 49 Stat. 854,16 U.S.C. $825-825$ b.

20/ Beginning with F.Y. 1953 this audit has been made by the Comptroller General pursuant to the Budget and Accounting Act of 1921 (31 U.S.C. 53) and section 117 of the Accounting and Auditing Act of 1950, 64 Stat. 837, 31 U.S.C. 67.

21/ Section 11 of the Federal Columbia River Transmission System Act, cited in note 1 , supra, authorizes the Administrator to make expenditures from the Bonneville Power Administration fund which were included in its annual budget submitted to and approved by 
Congress, "without further appropriation and without fiscal. year limitation, but within such specific directives or limitations as may be included in appropriation acts, for any purpose necessary or appropriate to carry out the duties imposed upon the Administrator pursuant to law." Limitations on expenditures for such things as passenger vehicles aircraft, law books, typewriters, and attendance at meetings are sometimes provided for in various appropriation acts including the annual General Government Matturs Appropriation Acts or other provisions of law.

22/ Subsection 9(c) was repealed by Act of June 14, 1966, P.L. 89-448, section 2, 80 Stat. 200. In lieu thereof, that act, as amended by section 6 of the Act of September 7, 1966, P.L. 89-561, 80 Stat. 707, 714, added the following material now set out in 16 U.S.C. 835j-835m (1964 Edition, Șupp. IV):

"SEC. 2(a) The Secretary of the Interior shall prepare, maintain, and present annually to the President and the Congress a consolidated financial statement for all projects heretofore or hereafter authorized, including the third powerplant at Grand Coulee Dam, from or by means of which commercial power and energy is marketed through the facilities of the Federal Columbia River power system and for all other projects associated therewith to the extent that the costs of these projects are required by law to be charged to and returned from net revenues derived from the power and energy, or any power and energy, so marketed, and he shall, if said consolidated statement indicates that the reimbursable construction costs of the projects, or any of the projects, covered thereby which are chargeable to and returnable from the commercial power and energy so marketed are likely not to be returned within the period prescribed by law, take prompt action to adjust the rates charged for such power and energy to the extent necessary to assure such return. Section 9, subsection (c) of the Act of August 20, 1937 (50 Stat. 736), as amended (16 U.S.C. 832h) is hereby repealed. [ 80 Stat. 200 as redesignated by 80 Stat. $714 ; 16$ U.S.C. 835 j (1964 Edition, Supp. IV)]

"Subject to the provisions of subsection (b) of this section, that portion of the construction cost of any project hereafter authorized to be constructed, operated, and maintained by the Secretary of the Interior under the Federal reclamation laws (Act of June 17, 1902, 32 Stat. 388, and Acts amendatory thereof or supplementary thereto) within the Pacific Northwest which, though allocated to irrigation, is beyond the ability of the irrigation water users to repay within the repayment period prescribed by law for that project and cannot be returned within the same period from other project sources of revenue shall be charged to and returned within that period from net revenues derived from the marketing of commercial power and energy through the Federal Columbia River power system, unless otherwise provided by law. As used in this Act, the term "Pacific Northwest" has the meaning ascribed to it in section 1 of the Act of August 31, 1964 (78 Stat. 756). [80 Stat. 200 as amended by 80 Stat. 714; 16 U.S.C. 835k (1964 Edition, Supp. IV)]

"(b) It is declared to be the policy of the Congress that reclamation projects hereafter authorized in the Pacific Northwest to receive financial assistance from the Federal Columbia River power system shall receive such assistance only from the net revenues of that system as provided in this subsection, and that their construction shall be so scheduled that such assistance, together with similar assistance for previously authorized reclamation projects (including projects not now receiving such assistance for which the Congress may hereafter authorize financial assistance) will not cause increases in the rates and charges of the Bonneville Power Administration. It is further declared to be the policy of the Congress that the total assistance to all irrigation projects, both existing and future, in the Pacific Northwest shall not average more than 
$\$ 30,000,000$ annually in any period of twenty consecutive years. Any analyses and studies authorized by the Congress for reclamation projects in the Pacific Northwest shall be prepared in accordance with the provisions of this section. As used in this section, the term "net revenues" means revenues as determined from time to time which are not required for the repayment of (1) all costs allocated to power at projects in the Pacific Northwest then existing or authorized, including the cost of acquiring power by purchase or exchange, and (2) presently authorized assistance from power to irrigation at projects in the Pacific Northwest existing and authorized prior to the date of enactment of this subsection. [80 Stat. 714 ; 16 U.S.C. 835 l (1964 Edition, Supp. IV)]

"(c) On December 20, 1974, and thereafter at intervals coinciding with anniversary dates of Federal Power Commission general review of the rates and charges of the Bonneville Power Administration, the Secretary of the Interior shall recommend to the Congress any changes in the dollar limitations herein placed upon financial assistance to Pacific Northwest reclamation projects that he believes iustified by changes in the cost-price levels existing on July 1, 1966, or by other relevant changes of circumstances. [80 Stat. 714; 16 U.S.C. $835 \mathrm{~m}$ (1964 Edition, Supp. IV)]"

23/ The duties of General Counsel have been transferred to the Regional Solicitor, Portland Region, Office of the Solicitor. 200 Departmental Manual 2.1.D(1), 25 F.R. 324; 210 Departmental Manual 2.1, 24 F.R. 1348; and Solicitor's Memoranda of May 3, 1954, and August 31. 1954, approved by Secretary May 4, 1954, and September 3, 1954, respectively.

24/ The words "the Classification Act of 1923, as amended, and" have been omitted following the words "fix their compensation without regard to" and the words "the Classification Act of 1949, as amended, and" have been inserted at the place shown in accordance with former section 201 (b) of the Act of October 28, 1949, 63 Stat. 9\&4, now 5 U.S.C. 5102.5 U.S.C. 5102 and 5341 (which replaced section 202 of the Act of October 28, 1949, as amended) provide that the Classification Act shall not apply to "(7) employees in recognized trades or crafts or other skilled mechanical crafts, or in unskilled, semi-skilled or skilled manual-labor occupations, and other employees including foremen and supervisors in positions having trade, craft, or laboring experience and knowledge as the paramount requirement ** " " (5 U.S.C. 5102) "The pay of [such] employees *** shall be fixed and adjusted from time to time as nearly as is consistent with the public interest in accordance with prevailing rates * * " (5 U.S.C. 5341). See decision of the Comptroller General, No. B-138063 of February 11, 1959, 38 Comp. Gen. 538.

25/ The provision in the Act reads " *** and to fix the compensation of each of such experts without regard to the Classification Act of 1923 , as amended, but at not to exceed $\$ 7,500$ per annum." It has been changed to read as shown pursuant to the provisions of former section 201 (b) of the Act of October 28, 1949, cited in note 22, supra. Prior to 1949 the monetary salary limitation had been raised to $\$ 8,880$ per annum by virtue of section 4 of the Act of May 24, 1946, 60 Stat. 216, and section 301 of the Act of July 3, 1948, 62 Stat. 1260. For general authority of agencies to hire experts and consultants, see 5 U.S.C. 3109 and the per diem limitations contained in applicable appropriation acts.

26/ This authority is now limited to claims which do not come under the provisions of the Federal Tori Claims Act. See sections $424(a)$ and $424(b)$ of the Act of August 2, 1946, 60 Stat. 846,847 and Revisor's note to 28 U.S.C. 2680.

27/ This authority has now been delegated to the Regional Solicitor, Portland. 1210 Departmental Manual 2.2B(1), 24 F.R. 1348, and Solicitor's Regulation 5, as amended, 30 F.R. 12956) as well as to the Administrator under Secretary's Order 2860, cited in note 1, supra. 
28/ The word "private" includes non-Federal public property. Cf. 38 Opinions of the Attorney General 514 (1936).

29/ The regularly employed attorneys of the various agencies of the Department of the Interior have been integrated under the Office of the Solicitor of the Department of the Interior. See note 23, supra. 
Public Law 93-454

93rd Congress, S. 3362

October 18, 1974

\section{AN ACT}

To enable the Secretary of the Interior to provide for the operation, maintenance, and continued construction of the Federal transmission system in the Pacitic Northwest by use of the revenues of the Federal Columbia River Power System and the proceeds of revenue bonds, and for other purposes.

Be it enacted by the Senate and House of Representatives of the United States of America in Congress assembled, This Act may be cited as the "Federal Columbia River Transmission System Act".

SEC. 2. (a) Congress finds that in order to enable the Secretary of the Interior to carry out the policies of Public Law 88-552 relating to the marketing of electric power from hydroelectric projects in the Pacific Northwest, Public Laws 89-448 and 89-561 relating to use of revenues of the Federal Columbia River Power System to provide financial assistance to reclamation projects in the Pacific Northwest, the treaty between the United States and Canada relating to the cooperative development of the resources of the Columbia River Basin, and other applicable law, it is desirable and appropriate that the revenues of the Federal Columbia River Power System and the proceeds of revenue bonds be used to further the operation, maintenance, and further construction of the Federal transmission system in the Pacific Northwest.

(b) Other than as specifically provided herein, the present authority and duties of the Secretary of the Interior relating to the Federal Columbia River Power System shall not be affected by this Act. The authority and duties of the Administrator referred to herein are subject to the supervision and direction of the Secretary.

SEC. 3. As used in this Act --

(a) The term "Administrator" means the Administrator, Bonneville

Power Administration.

(b) The term "electric power" means electric peaking capacity or electric energy, or both.

(c) The term "major transmission facilities" means transmission facilities intended to be used to provide services not previously provided by the Bonneville Power Administration with its own facilities.

SEC. 4. The Secretary of the Interior, acting by and through the Administrator, shall operate and maintain the Federal transmission system

16 USC 838a.

Federal Columbia River Transmission System Act. 16 USC 838 note.

16 USC 837.

16 USC $835 j-835 m$. 16 USC 838.

16 USC 838b. 
Transmission facilities, acquisition by condemnation, restriction. 16 USC 838c.

16 USC 838d.

16 USC 838e.

16 USC 838f.

16 USC 838g. within the Pacific Northwest and shall construct improvements, betterments, and additions to and replacements of such system within the Pacific Northwest as he determines are appropriate and required to:

(a) Integrate and transmit the electric power from existing or additional Federal or non-Federal generating units;

(b) provide service to the Administrator's customers;

(c) provide interregional transmission facilities; or

(d) maintain the electrical stability and electricai reliability of the Federal system: Provided, however, That the Administrator shall not construct any transmission facilities outside the Pacific Northwest, excepting customer service facilities within any contiguous areas, not in excess of seventy-five airline miles from said region, which are a part of the service area of a distribution cooperative which has (i) no generating facilities, and (ii) a distribution system from which it serves both within and without said region, nor shall he commence construction of any major transmission facility within the Pacific Northwest, unless the expenditure of the funds for the initiation of such construction is specifically approved by Act of Congress.

SEC. 5. (1) Unless specifically authorized by Act of Congress, the Administrator shall not expend funds made available under this Act, other than funds specifically appropriated by the Congress for such purpose, to acquire any operating transmission facility by condemnation: Provided, That this provision shall not restrict the acquisition of the right to cross such a facilit" by condemnation.

(b) At least sixty days prior to the time a request for approval or authority under section 4 or 5 of this Aict is sent to Congress, the Administrator shall give notice of such request to entities in the Pacific Northwest with which the Administrator has power sales or exchange contracts or transmission contracts or which have a transmission interconnection with the Federal transmission system.

SEC. 6. The Administrator shall make available to all utilities on a fair and nondiscriminatory basis, any capacity in the Federal transmission system which he determines to be in excess of the capacity required to transmit electric power generated or acquired by the United States.

SEC. 7. Subject to the provisions of section 5 of this Act the Administrator may purchase or lease or otherwise acquire and hold such real and personal property in the name of the United States as he deems necessary or appropriate to carry out his duties pursuant to law.

SEC. 8. The Administrator is hereby designated as the marketing agent for all electric power generated by Federal generating plants in the Pacific Northwest, constructed by, under construction by, or presently authorized for construction by the Bureau of Reclamation or the United States Corps of Engineers except electric power required for the operation of each Federal project and except electric power from the Green Springs project of the Bureau of Reclamation.

SEC. 9. Schedules of rates and charges for the sale, including dispositions to Federal agencies, of all electric power made available to the Administrator pursuant to section 8 of this Act or otherwise acquired, and for the transmission of non-Federal electric power over the Federal transmission system, 
shall become effective upon confirmation and approval thereof by the Federal Power Commission. Such rate schedules may be modified from time to time by the Secretary of the Interior, acting by and through the Administrator, subject to confirmation and approval by the Federal Power Commission, and shall be fixed and established (1) with a view to encouraging the widest possible diversified use of electric power at the lowest possible rates to consumers consistent with sound business principles, (2) having regard to the recovery (upon the basis of the application of such rate schedules to the capacity of the electric facilities of the projects) of the cost of producing and transmitting such electric power, including the amortization of the capital investment allocated to power over a reasonable period of years and payments provided for in section $11(b)(9)$, and (3) at levels to produce such additional revenues as may be required, in the aggregate with all other revenues of the Administrator, to pay when due the principal of, premiums, discounts, and expenses in connection with the issuance of and interest on all bo: ids issued and outstanding pursuant to this Act, and amounts required to establish and maintain reserve and other funds and accounts established in connection therewith.

SEC. 10. The said schedules of rates and sharges for transmission, the said schedules of rates and charges for the sale of electric power, or both such schedules, may provide, among other things, for uniform rates or rates uniform throughout prescribed transmission areas. The recovery of the cost of the Federal transmission system shall be equitably allocated between Federal and non-Federal power utilizing such system.

SEC. 11. (a) There is hereby established in the Treasury of the United States a Bonneville Power Administration fund (hereinafter referred to as the "fund"). The fund shall consist of (1) all receipts, collections, and recoveries of the Administrator in cash from all sources, including trust funds, (2) all proceeds derived from the sale of bonds by the Administrator, (3) any appropriations made by the Congress for the fund, and (4) the following funds which are hereby transferred to the Administrator: (i) all moneys in the special account in the Treasury established pursuant to Executive Order Numbered 8526 dated August 26, 1940, (ii) the unexpended balances in the continuing fund established by the provisions of section 11 of the Bonneville Project Act of August 20, 1937 (16 U.S.C. 831 et seq.), and (iii) the unexpended balances of funds appropriated or otherwise made available for the Bonneville Power Administration. All funds transferred hereunder shall be available for expenditure by the Secretary of the Interior, actirig by and through the Administrator, as authorized in this Act and any other Act relating to the Federal Columbia River transmission system, subject to such limitations as may be prescribed by any applicable appropriation act effective during such period as may elapse between their transfer and the approval by the Congress of the first subsequent annual budget program of the Administrator.

(b) The Administrator may make expenditures from the fund, which shall have been included in his annual budget submitted to Congress, without further appropriation and without fiscal year limitation, but within such specific directives or limitations as may be included in appropriation acts, for any purpose necessary or appropriate to carry out the duties imposed upon the Administrator pursuant to law, including but not limited to -- 
(1) construction, acquisition, and replacement of (i) the transmission system, including facilities and structures appurtenant thereto, and (ii) additions, improvements, and betterments thereto (hereinafter in this Act referred to as "transmission system");

(2) operation, maintenance, repair, and relocation, to the extent such relocation is not provided for under subsection (1) above, of the transmission system;

(3) electrical research, development, experimentation, tests, and investigation related to construction, operation, and maintenance of tiansmission systems and facilities;

(4) marketing of electric power;

(5) transmission over facilities of others and rental, lease, cr leasepurchase of facilities;

(6) purchase of electric power (including the entitlement of electric plant capability) (i) on a short-term basis to meet temporary deficiencies in electric power which the Administrator is obligated by contract to supply, or (ii) if such purchase has been heretofore authorized or is made with funds expressly appropriated for such purchase by the Congress, or (iii) if to be paid for with funds provided by other entities for such purpose under a trust or agency arrangement;

(7) defraying emergency expenses or insuring continuous operation;

(8) paying the interest on, premiums, discounts, and expenses, if any, in connection with the issuance of, and principal of all bonds issued under section 13(a) of this Act, including provision for and maintenance of reserve and other funds established in connection therewith;

(9) making such payments to the credit of the reclamation fund or other funds as are required by or pursuant to law to be made into such funds in connection with reclamation projects in the Pacific Northwest: Provided, That this clause shall not be construed as permitting the use of revenues for repayment of costs allocated to irrigation at any project except as otherwise expressly authorized by law;

(10) making payments to the credit of miscellaneous receipts of the Treasury for all unpaid costs required by or pursuant to law to be charged to and returned to the general fund of the Treasury for the repayment of the Federal investment in the Federal Columbia River Power System from electric power marketed by the Administrator; and

(11) acquiring such goods and services, and paying dues and membership fees in such professional, utility, industry, and other societies, associations, and institutes, together with expenses related to such memberships, including but not limited to the acquisitions and payments set forth in the general provisions of the annual appropriations Act for the Department of Interior, as the Administrator determines to be necessary or appropriate in carrying out the purposes of this Act.

(c) Moneys heretofore or hereafter appropriated shall be used only for the purposes for which appropriated, and moneys received by the Administrator in trust shall be used only for carrying out such trust. The provisions of the Government Corporation Control Act (31 U.S.C. 841 et seq.) shall be applicable to the Administrator in the same manner as they are applied to the 
wholly owned Government corporations named in section 101 of such Act (31 U.S.C. 846), but nothing in the proviso of section 850 of title 31, United States Code, shall be construed as affecting the powers granted in subsection (b)(11) of this section and in sections 2(f), 10(b), and 12(a) of the Bonneville Project Act (16 U.S.C. 832 et seq.).

(d) Notwithstanding the provisions of sections 105 and 106 of the Government Corporation Control Act, the financial transactions of the Administrator shall be audited by the Comptroller General at such times and to such extent as the Comptroller General deems necessary, and reports of the results of each such audit shall be made to the Congress within $6-1 / 2$ months following the end of the fiscal year covered by the audit.

SEC. 12. (a) If the Administrator determines that moneys in the fund are in excess of current needs he may request the investment of such amounts as he deems advisable by the Secretary of the Treasury in direct, general obligations of, or obligations guaranteed as to both principal and interest by, the United States of America.

(b) With the approval of the Secretary of the Treasury, the Administrator may deposit moneys of the fund in any Federal Reserve bank or other depository for funds of the United States of America, or in such other banks and financial institutions and under such terms and conditions as the Administrator and the Secretary of the Treasury may mutually agree.

SEC. 13. (a) The Administrator is authorized to issue and sell to the Secretary of the Treasury from time to time in the name and for and on behalf of the Bonneville Power Administration bonds, notes, and other evidences of indebtedness (in this Act collectively referred to as "bonds") to assist in financing the construction, acquisition, and replacement of the transmission system, and to issue and sell bonds to refund such bonds. Such bonds shall be in such forms and denominations, bear such maturities, and be subject to such terms and conditions as may be prescribed by the Secretary of the Treasury taking into account terms and conditions prevailing in the market for similar bonds, the useful life of the facilities for which the bonds are issued, and financing practices of the utility industry. Refunding provisions may be prescribed by the Administrator. Such bonds shall bear interest at a rate determined by the Secretary of the Treasury taking into consideration the current average market yield on outstanding marketable obligations of the United States of comparable maturities, plus an amount in the judgment of the Secretary of the Treasury to provide for a rate comparable to the rates prevailing in the market for similar bonds. The aggregate principal amount of any such bonds outstanding at any one time shall not exceed $\$ 1,250,000,000$.

(b) The principal of, premiums, if any, and interest on such bonds shall be payable solely from the Administrator's net proceeds as hereinafter defined. "Net proceeds" shall mean for the purposes of this section the remainder of the Administrator's gross receipts from all sources after first deducting trust funds and the costs listed in section $11(\mathrm{~b})(2)$ through $11(\mathrm{~b})(7)$ and $11(\mathrm{~b})(11)$, and shall include reserve or other funds created from such receipts.

(c) The Secretary of the Treasury shall purchase forthwith any bonds issued by the Administrator under this Act and for that purpose is authorized to use as a public debt transaction the proceeds from the sale of any securities

Sale and issuance. 16 USC 838k.

Terms and conditions.

Interest rate, determination.

Limitation.

"Net proceeds."

Bonds, purchase.

31 USC 774. 
issued under the Second Liberty Bond Act, as now or hereafter in force, and the purposes for which securities may be issued under the Second Liberty Bond Act, as now or hereafter in force, are extended to include any purchases of the bonds issued by the Administrator under this Act. The Secretary of the Treasury may, at any time, sell any of the bonds acquired by him under this Act. All redemptions, purchases, and sales by the Secretary of the Treasury of such bonds shall be treated as public debt transactions of the United States.

Approved October 18, 1974.

LEGISLATIVE HISTORY:

HOUSE REPORT No. 93-1375 (Comm. on Interior and Insular Affairs).

SENATE REPORT No. 93-1030 (Comm. on Interior and Insular Affairs).

CONGRESSIONAL RECORD, Vol. 120 (1974):

July 30 , considered and passed Senate.

Oct. 7, considered and passed House.

WEEKLY COMPILATION OF PRESIDENTIAL DOCUMENTS, Vol. 10, No. 43:

Oct. 19, Presidential statement. 


\section{P. L. 88-552}

Act of August 31, 1964, 78 Stat. 756, 16 U.S.C. 837-837h

[Public No. 552 (S. 1007) - 88th Congress 2d Session]

\section{AN ACT}

To guarantee electric consumers in the Pacific Northwest first call on electric energy generated at Federal hydroelectric plants in that region and to guarantee electric consumers in other regions reciprocal priority, and for othei purposes.

Be it enauted by the Senate and House of Representatives of the United States of America in Congress assembled, That, as used in this Act --

(a) "Secretary" means the Secretary of the Interior.

(b) "Pacific Northwest" means (1) the region consisting of the States of Oregon and Washington, the State of Montana west of the Continental Divide, and such portions of the States of Nevada, Utah, and Wyoming within the Columbia drainage basin and of the State of Idaho as the Secretary may determine to be within the marketing area of the Federal Columbia River power system, and (2) any contiguous areas, not in excess of seventy-five airline miles from said region, which are a part of the service area of a distribution cooperative which has (i) no generating facilities, and (ii) a distribution system from which it serves both within and without said region.

(c) "Surplus energy" means electric energy generated at Federal hydroelectric plants in the Pacific Northwest which would otherwise be wasted because of the lack of a market therefor in the Pacific Northwest at any established rate.

(d) "Surplus peaking capacity" means electric peaking capacity at Federal hydroelectric plants in the Pacific Northwest for which there is no demand in the Pacific Northwest at any established rate.

(e) "Non-Federal utility" means any utility not owned or controlled by the United States, including any entity (1) which such a utility owns or controls, in whole or in part, or is controlled by, (2) which is controlled by those controlling such utility, or (3) of which such utility is a member.

(f) "Energy requirements of any Pacific Northwest customer" means the full requirements for electric energy of (1) any purchaser from the United States for direct consumption in the Pacific Northwest, and (2) any nonFederal utility in that region in excess of (i) the hydroelectric energy available for its own use from its generating plants in the Pacific Northwest, and (ii) any additional energy available for use in the Pacific Northwest which, under a then existing contract, the utility (A) can obtain at no higher incremental cost than the rate charged by the United States, or (B) is required to accept. 
Notice to purchasers.

Deliveries. (g) Terms not defined herein shall, unless the context requires otherwise, have the meaning given them in the March 1949 Glossary of Important Power and Rate Terms prepared under the supervision of the Federal Power Commission. [16 U.S.C. 837.]

SEC. 2. Subject to the provisions of this Act, the sale, delivery, and exchange of electric energy generated at, and peaking capacity of, Federal hydroelectric plants in the Pacific Northwest for use outside the Pacific Northwest shall be limited to surplus energy and surplus peaking capacity. At least 30 days prior to the execution of any contract for the sale, delivery, or exchange of surplus energy or surplus peaking capacity for use outside the Pacific Northwest, the Secretary shall give the then customers of the Bonneville Power Administration written notice that negotiations for such a contract are pending, and thereafter, at any customer's request, make available for its inspection current drafts of the proposed contract. [16 U.S.C. 837a.]

SEC. 3. (a) Any contract for the sale or exchange of surplus energy for use outside the Pacific Northwest, or as replacement, directly or indirectly, within the Pacific Northwest for hydroelectric energy delivered for use outside that region by a non-Federal utility, shall provide that the Secretary, after giving the purchaser notice not in excess of sixty days, will not deliver electric energy under such contract whenever.it can reasonably be foreseen that such delivery would impair his ability to meet, either at or after the time of such delivery, the energy requirements of any Pacific Northwest customer. The purchaser shall obligate himself not to take delivery of or use any such energy to supply any load under such conditions that discontinuance of deliveries from the Pacific Northwest in sixty days would cause undue hardship to the purchaser or in his territory, and, further, the purchaser shall acknowledge full responsibility if any such hardship occurs. Deliveries by a non-Federal utility from its generating plants in the Pacific Northwest for use on its own distribution system in an area outside but contiguous to the Pacific Northwest (not including any extension of its outside service area by merger or acquisition after the effective date of this Act) shall not be deemed deliveries by such utility for use outside the Pacific Northwest.

(b) Electric energy generated at Federal hydroelectric plants in the Pacific Northwest which can be conserved, for which there is no immediate demand in the Pacific Northwest at any established rate, but for which the Secretary determines there may be a demand in meeting the future requirements of the Pacific Northwest, may to delivered for use outside that region only on a provisional basis under contracts providing that if the Secretary determines at a subsequent time that, by virtue of prior deliveries under such contract, the Secretary is or will be unable to meet the energy requirements of any Pacific Northwest customer, the purchaser will return the full amount of energy delivered to him, or such portion or portions thereof as may be required, at such time or times as may be, specified by the Secretary, except that the Secretary shall not require return during the purchaser's daily peak periods. The Secretary shall require the return of the energy provisionally delivered hereunder, to such extent and at such times, as may be necessary to meet demands at any established rate for use within the Pacific Northwest. 
(c) Any contract for the disposition of surplus peaking capacity shall provide that (1) the Secretary may terminate the contract upon notice not in excess of sixty months, and (2) the purchaser shall advance or return the energy necessary to supply the peaking capacity, except that the Secretary shall not require such advance or return during the purchaser's daily peak periods. The Secretary may contract for the sale of such energy to the purchaser, in lieu of its return, under the conditions prescribed in subsection (a) of this section.

(d) The Secretary, in making any determination of the energy requirements of any Pacific Northwest customer which is a non-Federal utility having hydroelectric generating facilities, shall exclude any amounts of hydroelectric energy generated in the Pacific Northwest and disposed of outside the Pacific Northwest by the utility which, through reasonable measures, could have been conserved or otherwise kept available for the utility's own needs in the Pacific Northwest. The Secretary may seli the utility as a replacement therefor only what would otherwise be surplus energy. [16 U.S.C. 837b.]

SEC. 4. Any contract of the Secretary for the sale or exchange of electric energy generated at, or peaking capacity of, Federal hydroelectric plants in marketing areas outside the Pacific Northwest for use within the Pacific Northwest shall be subject to limitations and conditions corresponding to those provided in sections $\mathbf{2}$ and $\mathbf{3}$ for any contract for the sale or exchange of hydroelectric energy or peaking capacity generated within the Pacific Northwest for use outside the Pacific Northwest. [16 U.S.C. 837c.]

SEC. 5. Without regard to the limitations specified in sections 2 and 3 of this Act, the Secretary may enter into contracts for the exchange with areas other than the Pacific Northwest of (1) surplus energy during the Pacific Northwest storage refill period, (2) any hydroelectric energy during the Pacific Northwest storage refill period which will be returned to the Pacific Northwest in equal amounts during the same Pacific Northwest refill period or the succeeding storage drawdown period, (3) any hydroelectric energy which will be returned to the Pacific Northwest in equal amounts during the same Pacific Northwest storage drawdown period, (4) hydroelectric peaking capacity, or (5) surplus peaking capacity for energy. All benefits from such exchanges, including resulting increases of firm power, shall be shared equitably by the areas involved, having regard to the secondary energy and other contributions made by each. [16 U.S.C. 837d.]

SEC. 6. Any capacity in Federal transmission lines connecting, either by themselves or with non-Federal lines, a generating plant in the Pacific Northwest or Canada with the other area or with any other area outside the Pacific Northwest, which is not required for the transmission of Federal energy or the energy described in section 9, shall be made available as a carrier for transmission of other electric energy between such areas. The transmission of other electric energy shall be at equitable rates determined by the Secretary, but such rates shall be subject to equitable adjustment at appropriate intervals not less frequently than once in every five years as agreed to by the parties. No contract for the transmission of non-Federal energy on a firm basis shall be affected by any increase, subsequent to the execution of such contract, in the requirements for transmission of Federal energy, the energy described in section 9, or other electric energy. [16 U.S.C. 837e.] 
SEC. 7. The Secretary shall offer to amend, without imposing any other requirement as a condition to such amendment, all existing contracts for the sale or exchange of electric power generated at Federal hydroelectric plants in the Pacific Northwest to include, and shall include in all new contracts, provisions giving the purchaser priority on electric power generated at such plants in conformity with the provisions of this Act. [16 U.S.C. 837f.]

SEC. 8. No electric transmission lines or related facilities shall be constructed by any Federal agency outside the Pacific Northwest for the purpose of transmitting electric energy between the Pacific Northwest and Pacific Southwest, nor shall any arrangement for transmission capacity be executed by any Federal agency for the purpose of financing such lines and related facilities to be constructed by non-Federal entities, except those lines and facilities recommended for Federal construction in the Report of the Secretary of the Interior submitted to Congress on June 24, 1964, as supplemented on July 27, 1964, or as hereafter specifically authorized by Congress: Provided, That, except with respect to electric transmission lines and related facilities for the purpose of transmitting electric energy between the two regions above mentioned, nothing herein shall be construed as expanding or diminishing in any way the present authority of the Secretary of the Interior to construct transmission lines to market power and energy. [16 U.S.C. 837g.]

SEC. 9. The provisions of this Act shall not be applicable to (1) the Canyon Ferry project and (2), except as provided in section 6, downstream power benefits to which Canada is entitied under the treaty between Canada and the United States relating to the cooperative development of the water resources of the Columbia River Basin, signed at Washington, January 17, 1961, nor to energy or capacity disposed of to Canada in any exchange pursuant to paragraph 1 or 2 of article VIII thereof. Nothing in this Act shall be construed to modify the geographical preference of power users in the State of Montana which is established by the Hungry Horse Dam Act (Act of June 4, 1944 [So in original; should be June 5, 1944], 58 Stat. 270), as amended. [16 U.S.C. 837h.] 
P. L. $78-329$

Act of June 5, 1944, 58 Stat. 270, 43 U.S.C. 593a

[Public No. 329 (H.R. 3570) - 78th Congress, 2d Session]

As amended by Act of May 29, 1958, 72 Stat. 147

[Public No. 428 (S. 847) - 85th Congress, 2d Session]

\section{AN ACT}

To provide for the partial construction of the Hungry Horse Dam on the South Fork of the Flathead River in the State of Montana, and for other purposes.

Be it enacted by the Senate and House of Representatives of the United States of America in Congress assembled, That for the purpose of irrigation and reclamation of arid lands, for controlling floods, improsing navigation, regulating the flow of the South Fork of the Flathead River, for the generation of electric energy, and for other beneficial uses primarily in the State of Montana but also in downstream areas, the Secretary of the Interior is authorized and directed to proceed as soon as practicable with the construction, operation, and maintenance of the proposed Hungry Horse Dam (including facilities for generating electric energy) on the South Fork of the Flathead River, Flathead County, Montana, to such a height as may be necessary to impound not less than one million acre-feet of water. The Hungry Horse project shall be subject to the Federal reclamation laws (Act of June 17, 1902 [32 Stat. 388] and Acts amendatory thereof or supplementary thereto).'

SEC. 2. The Secretary of the Interior is authorized to complete, as soon as the necessary additional material is available, the construction of the Hungry Horse Dam so as to provide a storage reservoir of the maximum usable and feasible capacity.

SEC. 3. The Secretary of the Interior is authorized to construct, operate, and maintain under the provisions of the Federal reclamation laws (Act of June 17, 1902, 32 Stat. 388 and Acts amendatory thereof or supplementary theretol, such additional works as he may deem necessary for irrigation pruposes. Such irrigation works may be undertaken only after a report and findings thereon have been made by the Secretary of the Interior as provided in such Federal reclamation laws; and, within the limits of the water users' repayment ability, such report may be predicated on allocation to irrigation of an appropriate portion of the cost of constructing said dam and reservoir. Said dam and reservoir and said irrigation works may be utilized for irrigation purposes only pursuant to the provisions of said Federal reclamation laws.

SEC. 4. There are authorized to be appropriated such sums as may be necessary to carry out the purposes of this Act.

Approved June 5, 1944.

1/ Act of May 28, 1958, 72 Stat. 147, 43 U.S.C. 593a [Pub. L. 85-428] provided that the Hungry Horse project shall be subject to the Federal reclamation laws. 

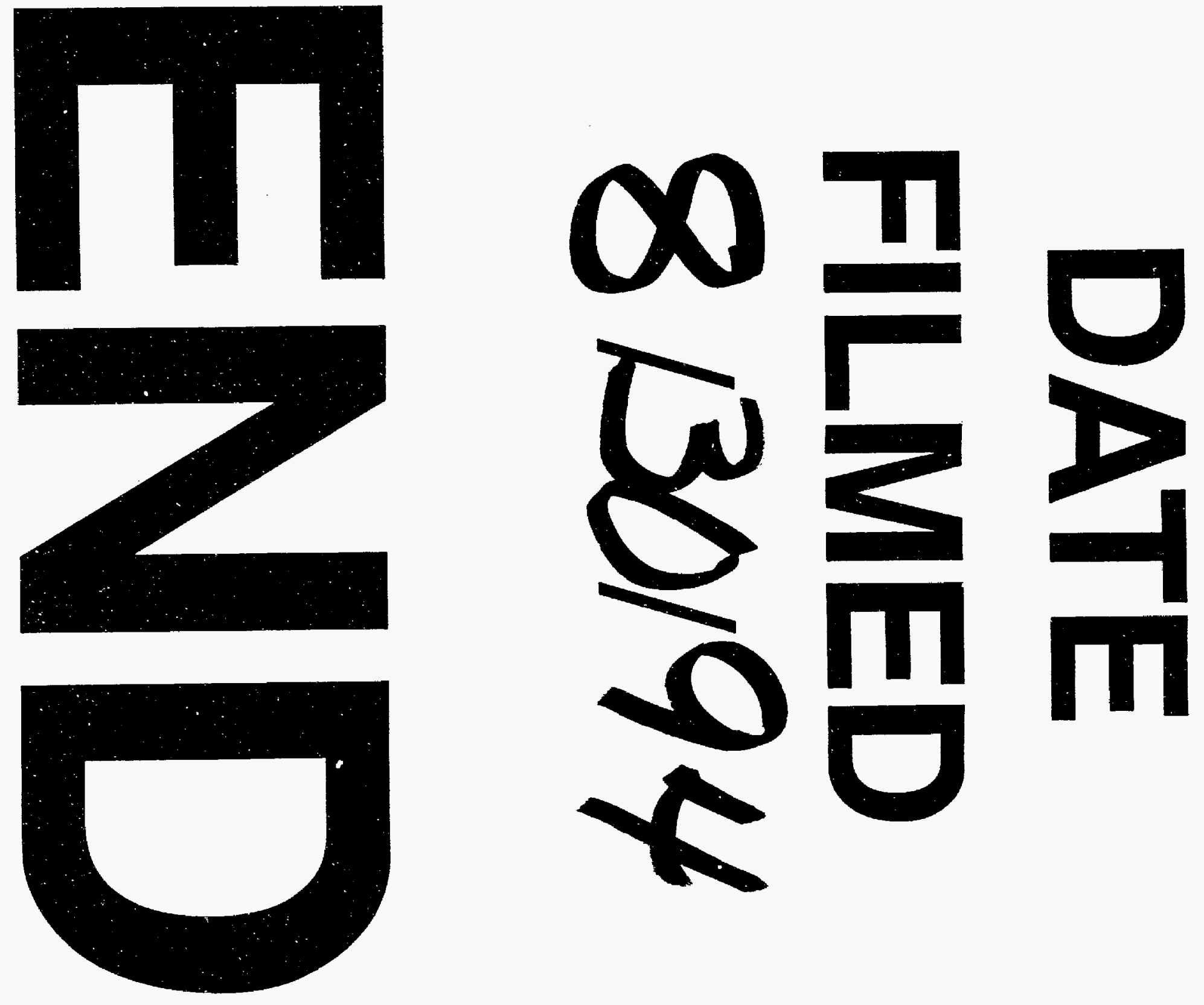
